\title{
Chemical profile of the twigs of Ozoroa obovata by HPLC-MS-ESI and antimicrobial activity
}

\author{
Perfil químico dos galhos de Ozoroa obovata por CLAE-EM-IES e atividade \\ antimicrobiana
}

\begin{abstract}
Domingos A. João',7; Tiara C. Silva1; Diego G. Prado1; Carlos H. G. Martins²; Mariana B. Santiago ${ }^{3}$; Luiz R. Goulart4; Mário M. Martins"; Francisco J. T. Aquino5; Alberto de Oliveira5; Raquel M. F. Sousa ${ }^{5}$; Luís C. S. Cunha6; Sérgio A. L. Morais ${ }^{5}$

${ }^{1}$ Aluno do Núcleo de Pesquisa em Produtos Naturais, Universidade Federal de Uberlândia, Uberlândia, Minas Gerais, Brasil. E-mail: d.augustojoao@gmail.com; diego_godina@yahoo.com.br; tiaracostak14@gmail.com;

${ }^{2}$ Professor do Laboratório de Pesquisa em Ensaios Antimicrobianos, Universidade Federal de Uberlândia, Uberlândia, Minas Gerais, Brasil. Orcid: https://orcid.org/0000-0001-8634-6878. E-mail: carlos.martins2@ufu.br

${ }^{3}$ Aluna do Laboratório de Pesquisa em Ensaios Antimicrobianos, Universidade Federal de Uberlândia, Uberlândia, Minas Gerais, Brasil. Orcid: https://orcid.org/0000-0002-6060-379X. E-mail: mari.brentini@hotmail.com

${ }^{4}$ Professor do Laboratório de Nanobiotecnologia, Universidade Federal de Uberlândia, Uberlândia, Minas Gerais, Brasil. E-mail: Irgoulart@ufu.br; mariomm1988@yahoo.com.br

${ }^{5}$ Professor do Núcleo de Pesquisa em Produtos Naturais, Universidade Federal de Uberlândia, Uberlândia, Minas Gerais, Brasil. E-mail: salemos@ufu.br, aquino@ufu.br, albertho.iq@gmail.com, rsousa@ufu.br

${ }_{6}$ Professor do Núcleo de Bioprospecção em Produtos Naturais, Instituto Federal do Triângulo Mineiro, Uberaba, Minas Gerais, Brasil. Orcid: https://orcid.org/0000-0002-4796-2480E-mail: luiscunha@iftm.edu.br

${ }^{7}$ Professor da Universidade Rovuma, Lichinga, Moçambique.
\end{abstract}

\begin{abstract}
In Mozambique, a large part of the population depends on plants for the treatment of various diseases. However, some of them have been little studied in relation to chemical and biological aspects. Among these species, Ozoroa obovata is widely used in traditional medicine in Mozambique. The factors that influence the use of medicinal plants in developing countries are mainly cultural habits, the inefficiency of the health system and the high cost of medicines. This work aimed to study the chemical composition and evaluate the antimicrobial activity of the twigs of $O$. obovata. Through the analysis by liquid chromatography coupled to mass spectrometry with electrospray ionization (HPLC-MS-ESI), it was possible to propose that in the ethanolic extract of the twigs, most of the constituents belong to the classes of phenolic acids and flavonoid. The phenolic compounds were represented by quinic, gallic and protocatechuic acids and five anacardic acids, whereas flavonoids were represented by mangiferin, taxifolin and quercetin mono and dihexoside. The extract was evaluated against bacteria in the oral cavity and showed moderate activity against Streptococcus mutans, $S$. mitis and Porphyromonas gingivalis (minimum inhibitory concentration - MIC $400 \mu \mathrm{g} \mathrm{mL}^{-1}$ ). In relation antifungal test, the extract showed activity against Candida albicans with MIC of $3000 \mu \mathrm{g} \mathrm{mL}^{-1}$. The biological results indicated that the twigs of $O$. obovata have bioactive metabolites with antimicrobial potential.
\end{abstract}

Keywords: antimicrobial activity, phenolics, flavonoids, Ozoroa obovata.

RESUMO: Em Moçambique, grande parte da população depende das plantas para o tratamento de várias doenças. No entanto, algumas delas foram pouco estudadas com relação aos aspectos químicos e biológicos. Dentre essas espécies, Ozoroa obovata é amplamente utilizada na medicina tradicional de Moçambique. Os fatores que influenciam o uso de plantas medicinais nos países em desenvolvimento são principalmente os hábitos culturais, a ineficácia do sistema de saúde e o elevado custo dos medicamentos. Este trabalho teve como objetivo estudar a composição química e avaliar a atividade antimicrobiana dos galhos de O. obovata. A partir da análise por cromatografia líquida acoplada a espectrometria de massas com ionização por electrospray (CLAE-EM-IES) foi possível propor que no extrato etanólico dos galhos, a maioria dos constituintes pertence as classes dos ácidos fenólicos e flavonoides. Os compostos fenólicos foram representados pelos ácidos quínico, gálico, protocatecuico e cinco ácidos anacárdicos, enquanto que os flavonoides foram representados por mangiferina, taxifolina e quercetina mono e dihexosídeo. $O$ extrato foi avaliado frente as bactérias da cavidade bucal e mostrou moderada atividade contra Streptococcus mutans, S. mitis e Porphyromonas gingivalis (concentração inibitória mínima - CIM $400 \mu \mathrm{g} \mathrm{mL}^{-1}$ ). Com relação ao ensaio antifúngico, o extrato etanólico apresentou atividade contra Candida albicans com CIM de $3000 \mu \mathrm{g}$ $\mathrm{mL}^{-1}$. Os resultados biológicos indicaram que os galhos de 0 . obovata possuem metabólitos bioativos com potencial antimicrobiano.

Palavras chave: atividade antimicrobiana, fenólicos, flavonoides, Ozoroa obovata. 


\section{INTRODUCTION}

Despite advances in the fields of science and medicine, diseases remain a serious threat to public health in developed and developing countries, urban and rural areas and all ethnic groups (PAN et al., 2014). It is estimated that in developing countries, a large part of the population depends on traditional practices and medicinal plants to meet basic health needs (SINGH, 2015). In countries where the population is most vulnerable to health problems, medicinal plants and herbal medicines play an important role in the treatment of diseases. For thousands of years, medicinal plants have been used in virtually all cultures as flavorings, preservatives in foods and as a source of medicines for the treatment and prevention of diseases (SINGH, 2015). Currently, plants are one of the main sources for the development of new drugs (NEWMAN; CRAGG, 2016, CALIXTO, 2019).

Particularly in Mozambique, trade and the use of various species of plants are strongly inserted in the daily life of the population. In Mozambique, bacterial and parasitic diseases contribute to a high rate of mortality and morbidity. Even with the intervention of antibiotics and antiparasitic drugs, the potential for treating some diseases has decreased due to the indiscriminate use of these drugs. As a result, the population has looked to medicinal plants for an alternative source for the treatment of diseases (SHARIFIFAR et al., 2016, BARBOSA et al., 2020).

In this context, Ozoroa obovata (Oliv.) R. \& A. Fer. (Anacardiaceae), is marketed and traditionally used in Mozambique for the treatment of dysentery, inflammation of the chest, respiratory infections, low back pain, cough, chest pain, fever, diarrhea, and wounds (BANDEIRA; GASPAR; PAGULA, 2001, GRACE et al., 2003, YORK; DE WET; VAN VUUREN, 2011, YORK; VAN VUUREN; DE WET, 2012, WÜRGER; MCGAW; ELOFF, 2014, SHARIFIFAR et al., 2016, BARBOSA et al., 2020). The potential against microorganisms that cause respiratory infections (YORK; VAN VUUREN; DE WET, 2012) and the presence of phenolic compounds (WÜRGER; MCGAW; ELOFF, 2014) in the leaves of $O$. obovata have already been reported. $O$. obovata is generally found in several South African countries such as Mozambique, Zimbabwe, Malawi and Tanzania (BANDEIRA; GASPAR; PAGULA, 2001, GRACE et al., 2003). Part of the economy and livelihood of the population of many of these countries depends on the exploration and trade of medicinal plants (TIMMERMANN; SMITH-HALL, 2020). However, the rapid growth of urbanization (BARBOSA et al., 2020), the destruction of forests by fire (MLIGO, 2019), overexploitation of plant resources, unsustainable harvesting practices (BRUSCHI et al., 2014), has aroused concern with the availability of these resources in the future (SEN; SAMANTA, 2014).

In Maputo (Mozambique), an important center for the collection and trade of medicinal plants, of the different parts of the plants explored by the population, $75 \%$ are roots, $10 \%$ leaves, $7 \%$ stems, $4 \%$ fruits and $4 \%$ other parts (BARBOSA et al., 2020). When the root is collected, the vegetable is removed permanently from its habitat. Thus, this type of practice, if not done in a planned way, can contribute to a decline in local and planetary biodiversity (SEN; SAMANTA, 2014). Therefore, it is of fundamental importance to investigate parts of the plant that preserve its integrity.

The prevalence of antibiotic-resistant microorganisms represents a great threat to public health, justifying the development of new strategies for the prevention and treatment of infectious diseases (SHARIFIFAR et al., 2016, HOKKEN et al., 2019). According to the World Health Organization, bacteria and fungi have been developing new resistance mechanisms resulting in ineffective treatments and longer illnesses leading to the patient's 
death (WHO, 2020). Microbial resistance is a natural phenomenon that occurs when microorganisms are treated with drugs, some susceptible are killed and the most resistant can survive and multiply making the drugs ineffective (PRESTINACI; PEZZOTTI; PANTOSTI, 2015). The microorganisms evaluated in the present work are related to diseases of the oral cavity and diseases caused by fungi. The oral bacteria tested promote diseases such as periodontitis, gingivitis and dental caries, in addition to systemic conditions that include cardiovascular and intestinal diseases, rheumatoid arthritis, brain abscesses, diabetes, among others (ZARCO; VESS; GINSBURG, 2011, CHIMENOS-KÜSTNER; GIOVANNONI; SCHEMEL-SUÁREZ, 2017). Fungi are involved with skin diseases and invasive infections such as fungemia, meningitis, pneumonia and pulmonary aspergillosis, bronchopulmonary allergies, asthma and obstructive pulmonary disease. (WHITE et al., 2014, PERLIN; RAUTEMAA-RICHARDSON; ALASTRUEY-IZQUIERDO, 2017, HOKKEN et al., 2019).

Within this work, the chemical composition by liquid chromatography coupled to mass spectrometry (HPLC-MS-ESI) and the antimicrobial activity of the twigs from 0 . obovata were investigated. Highlights here that the studies were focused on the twigs because the indications of popular use, chemical composition and biological properties are open in the literature.

\section{MATERIAL E METHODS}

\section{Extract preparation and phytochemical screening}

The twigs of $O$. obovata were collected in Maputo Province, Marracuene District, Mozambique. The species was identified by a specialist and a voucher specimen was deposited at the Herbarium of the Institute of Traditional and Alternative Medicine in Misau, Maputo-Mozambique under identification number 18. The samples were dried at room temperature for ten days and taken to Brazil at the Federal University of Uberlândia. The plant material was placed in a circulating air oven at $35^{\circ} \mathrm{C}$ and the moisture content was monitored in an infrared light balance (QUIMIS, model kett FD-600). The samples were removed from the oven when the moisture content was below $10 \%$. The dry vegetable material was ground $(61 \mathrm{~g})$ and then the ethanolic extract was prepared by maceration using ethanol $98 \%$ for 48 hours. This extraction procedure was repeated five times. The ethanolic extract (EE) was concentrated on a rotary evaporator (IKA, RV 10), lyophilized (TERRONI, LS3000) and finally stored in the freezer at $-5^{\circ} \mathrm{C}$.

Phytochemical screening was performed using Thin Layer Chromatography (CCD), with silica gel 60 plates and fluorescence indicator $\left(U_{254}\right)$. The extract was solubilized in ethanol and developed with the mobile phase consisting of hexane: ethyl acetate $(4: 1 \mathrm{v} / \mathrm{v})$. The following developing agents were used: iodocloroplatinate, dragendorff, $\mathrm{KOH}, \mathrm{NP} / \mathrm{PEG}$, sulfuric vanillin, Liebermann Burchard and ceric sulfate (WAGNER; BLADT, 1996).

\section{Analysis by High Performance Liquid Chromatography coupled to Mass Spectrometry (HPLC-MS)}

Analysis by HPLC-MS of the ethanolic extract of $O$. obovata, was carried out on a liquid chromatograph (Agilent, model Infinity 1260), coupled to a high-resolution mass spectrometer QTOF (Quadrupole Time of Flight - Agilent, model 6520 B), with electrospray 
ionization source (ESI). A volume of $1.0 \mu \mathrm{L}$ of the sample was injected into the chromatograph using a Agilent Zorbax C18 column $(2.1 \mathrm{~mm} \times 50 \mathrm{~mm}, 1.8 \mu \mathrm{m})$. The chromatographic conditions were ultrapure water with formic acid $(0.1 \%, \mathrm{v} / \mathrm{v})$ (mobile phase A) and methanol (mobile phase B). The gradient system was: 10\% B (0 min), 98\% B (0-10 min), remaining with $98 \% \mathrm{~B}(10-17 \mathrm{~min})$ with a flow of $0.6 \mathrm{~mL} \mathrm{~min}^{-1}$. The ionization

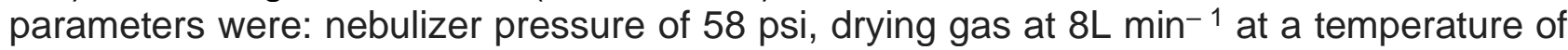
$220^{\circ} \mathrm{C}$ and an energy of $4.5 \mathrm{KV}$ was applied to the capillary. The analysis was performed in the negative mode $[\mathrm{M}-\mathrm{H}]^{-}$in high resolution (MS). The molecular formula was proposed for each compound according to a list suggested by the MassHunter® Software following the lowest difference between the experimental mass and the exact mass, error in ppm, unsaturation equivalence and nitrogen rule. The sequential mass spectrometry $\left(\mathrm{MS}^{2}\right)$ of the molecular ions was performed at different collision energies. The chemical composition of the extract was proposed comparing the mass spectra of fragments and the mass in high resolution obtained with other works in the literature and Metlin library.

\section{Antibacterial activity}

The evaluation of antibacterial activity of ethanol extract from 0 . obovata twigs was performed using the broth microdilution method according to Clinical and Laboratory Standards Institute (CLSI, 2012a, CLSI, 2012b). The microorganisms used in the tests of the antibacterial activity and their respective references from the American Type Culture Collection (ATCC, RockvilleMD, USA) were Streptococcus sanguinis (ATCC10556), Streptococcus mitis (ATCC49456), Streptococcus mutans (ATCC25175), Agreggatibacter actinomycetemcomitans (ATCC43717), Fusobacterium nucleatum (ATCC25586), Porphyromonas gingivalis (ATCC33277), Actinomyces naeslundii, (ATCC19039) and Bacteroides fragilis (ATCC25285). The tested concentrations varied between 400 to $25 \mu \mathrm{g}$ $\mathrm{mL}^{-1}$. The minimum inhibitory concentration (MIC) was correlated to the lowest concentration of extract capable of inhibiting the growth of the microorganisms. The details of the methodology, as well as the controls used to validate the results are described in the work by Rocha et al., 2018.

\section{Antifungal activity}

The evaluation of antifungal activity of ethanol extract from 0 . obovata twigs was performed using the broth microdilution method according to Clinical and Laboratory Standards Institute (CLSI, 2008). The following microorganisms from the American Type Culture Collection were used: Candida albicans (ATCC 28366), Candida tropicalis (ATCC 13803) and Candida glabrata (ATCC 15126). The tested concentrations varied between 3,000 to $1.46 \mu \mathrm{g} \mathrm{mL}^{-1}$. The entire procedure and controls used in the tests are available in Rocha et al., 2018.

\section{RESULTS AND DISCUSSION}

\section{Extract yield and phytochemical screening}

The EE of the twigs of $O$. obovata was prepared using the maceration technique, a process that occurs at room temperature allowing the extraction of the substances present 
in the extract without degradation (SIMOES et al., 2017). The yield of O. obovata ethanolic extract was $3.0 \mathrm{~g}$ in relation to the dry mass of the twigs $(4.9 \% \mathrm{~m} / \mathrm{m})$.

Preliminary phytochemical screening (Table 1) showed the presence of flavonoids and phenolic compounds. Alkaloids, anthraquinones, anthrones and coumarins were not found in the EE of O. obovata.

Table 1. Phytochemical screening of $O$. obovata extract

\begin{tabular}{ccc}
\hline Developers & Class of Compounds & Ethanol Extract \\
\hline NP/PEG & Flavonoids & ++ \\
lodocloroplatinate & Alkaloids & - \\
Dragendorff & Anthraquinones, anthrones and coumarins & - \\
KOH & Triterpenes and steroids & ++ \\
Liebermann Buchard & Terpenes and flavonoids & ++ \\
Ceric sulfate & Phenylpropanoids, tannins and flavonoids & ++ \\
Sulfuric vanillin & Phen \\
\hline
\end{tabular}

In literature, no studies using $O$. Obovata such as in this paper were found. However, other species of the genus have already been investigated. The phytochemical analysis of Ozoroa pulcherrima showed the presence of compounds such as phenols, flavonoids, terpenes, condensed and hydrolyzable tannins, triterpenes and saponins. (JATSA et al., 2019). Ozoroa paniculosa and Ozoroa Mucronata presented phenolic compounds, proanthocyanidins, galotanins and flavonoids (AHMED et al., 2014). Ozoroa insignis extracts showed the presence of hydrolyzable tannins, flavonoids, saponins, steroids and alkaloids (NYABERI et al., 2010).

\section{Identification of the compounds present in the ethanolic extract of the twigs of 0 . obovata by HPLC-MS-ESI.}

The proposal to identify the compounds present in the O. obovata extract was carried out from the analysis by HPLC-MS-ESI in the negative mode. The chromatogram represented in Figure 1 shows the chemical profile of the ethanolic extract. It was possible to propose the identification of 15 compounds (Table 2), through the mass of molecular ions in high resolution, error (ppm) and analysis of the fragmentation profile of the compounds, comparing with data from the literature and Metlin library. The proposed chemical structures are shown in Figure 2.

In the first 5.2 minutes of the chromatogram (Figure 1), it was possible to identify phenolic acids in which (1,2 and 3) corresponding to the compounds quinic, galic and protocatechuic, respectively, as well as compound 6, an ester of gallic acid. Between 5.5 and 7.0 minutes, the following compounds were identified: aglycone flavonoid as taxifolin (8) and hexosides flavonoids corresponding to the compounds mangiferin (7), quercetindihexoside I (10), quercetin-hexoside (11) and quercetin-dihexoside II (12). At 13.7 minutes (compound 16), was identified as palmitic acid. Finally, after 14.0 minutes, a series of phenolic acid derivatives with long chain were identified, these compounds correspond to anarcadic acids (18, 19, 20, 21, and 22). 
Figure 1. Chromatogram of the twigs of $O$. obovata obtained in the negative mode

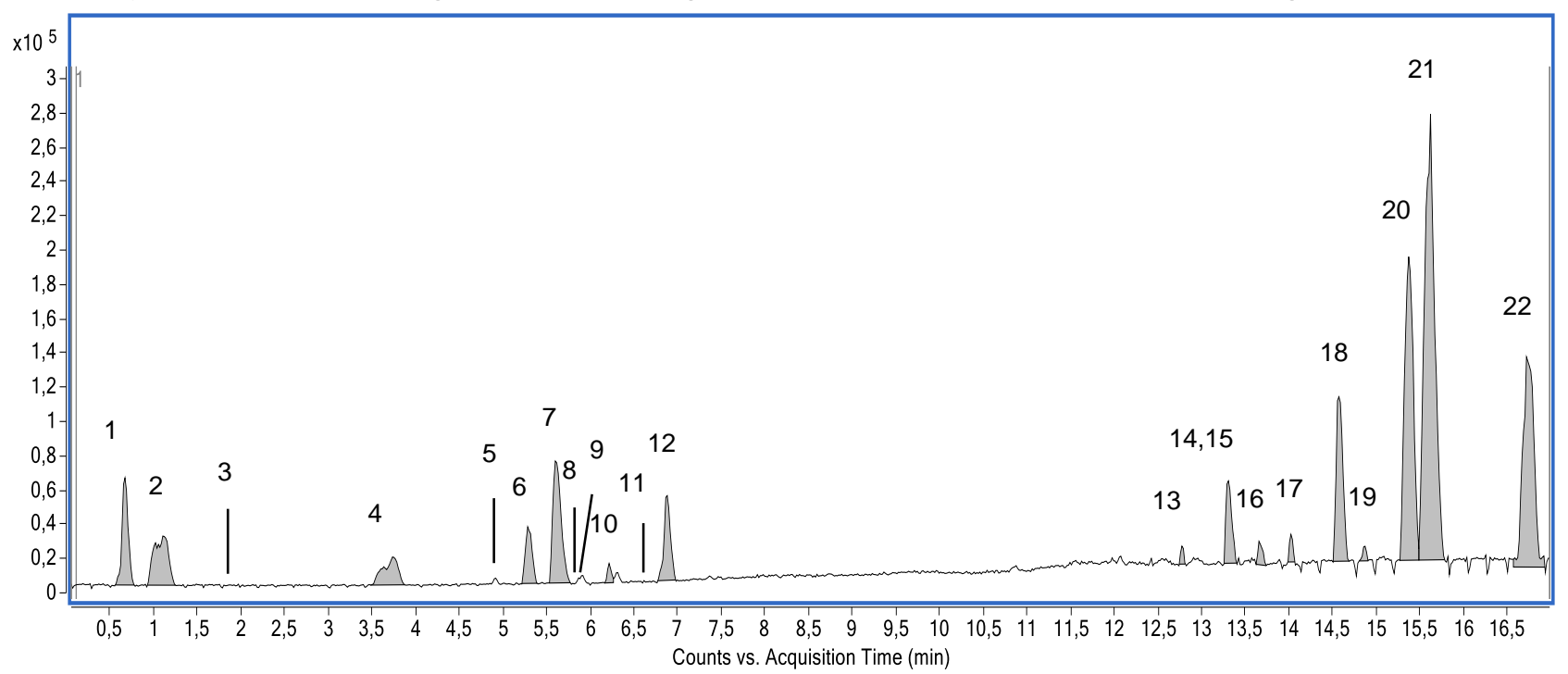

Chromatographic conditions: C18 column; gradient: methanol/water acidified with $0.1 \% \mathrm{v} / \mathrm{v}$ formic acid. $10-98 \%$ methanol (0-10 $\mathrm{min}), 98 \%$ methanol (10-17 $\mathrm{min})$.

Through the identification proposal it was possible to confirm the presence of flavonoids, phenolic compounds and derivatives that were evidenced in phytochemical screening. The chemical composition of other species of Ozoroa corroborate with some classes of compounds identified in $O$. obovata. From the roots of $O$. pulcherrima, a derivative of phenolic acid has been identified (JATSA et al., 2019) and two anacardic acids have already been isolated (CHRISTELLE et al., 2011). A flavonoid and several anacardic acids were isolated from the roots of $O$. insignis (LIU; ABREU, 2006, NG'ANG'A et al., 2009). These classes of metabolites have also been reported in the leaves of $O$. mucronata and $O$. paniculosa (AHMED et al., 2014). 
Revista Brasileira de Ciência, Tecnologia e Inovação

DOI: https://doi.org/10.18554/rbcti.v5i2.4359

Table 2. Proposal for identification of the compounds in the ethanolic extract of the twigs of O. obovate (To be continued)

\begin{tabular}{|c|c|c|c|c|c|c|c|c|}
\hline Num. & $\mathbf{R t}$ & {$[\mathrm{M}-\mathrm{H}]^{-}$} & Exact mass & $\begin{array}{l}\text { Error } \\
\text { (ppm) }\end{array}$ & Fragments $\mathrm{MS}^{2}(-)$ & $\begin{array}{l}\text { Molecular } \\
\text { formula }\end{array}$ & Tentative identity & Reference \\
\hline 1 & 0.77 & 191.0558 & 191.0561 & -1.57 & 20 eV: 173, 109 & $\mathrm{C}_{7} \mathrm{H}_{12} \mathrm{O}_{6}$ & Quinic acid & $\begin{array}{l}\text { Abu-Reidah et } \\
\text { al., } 2015\end{array}$ \\
\hline 2 & 0.93 & 169.0141 & 169.0142 & -0.59 & 20 eV: 125 & $\mathrm{C}_{7} \mathrm{H}_{6} \mathrm{O}_{5}$ & Gallic acid & $\begin{array}{c}\text { Wyrepkowski et } \\
\text { al., 2014; Erşan } \\
\text { et al., 2016; } \\
\text { Metlin }\end{array}$ \\
\hline 3 & 1.92 & 153.0191 & 153.0193 & -1.31 & 15 eV: 109, 108 & $\mathrm{C}_{7} \mathrm{H}_{6} \mathrm{O}_{4}$ & Protocatechuic acid & $\begin{array}{l}\text { SUN et al., } \\
\text { 2007, COSTA } \\
\text { SILVA et al., } \\
2019\end{array}$ \\
\hline 4 & 3.73 & 407.0984 & - & - & $\begin{array}{c}10 \text { eV: } 317,287,271 \\
245,145,193,161,125\end{array}$ & - & $\mathrm{NI}$ & - \\
\hline 5 & 4.91 & 421.1131 & - & - & $\begin{array}{c}10 \text { eV: } 301,258,207 \\
192,179\end{array}$ & - & $\mathrm{NI}$ & - \\
\hline 6 & 5.23 & 197.0455 & 197.0455 & 0.0 & 20 eV: 169; 125, 124 & $\mathrm{C}_{9} \mathrm{H}_{10} \mathrm{O}_{5}$ & Ethyl gallate & Sun et al., 2007 \\
\hline 7 & 5.66 & 421.0776 & 421.0776 & 0.0 & $\begin{array}{c}20 \text { eV: } 331,301,272 \\
271,259,258,243,215 \\
109\end{array}$ & $\mathrm{C}_{19} \mathrm{H}_{18} \mathrm{O}_{11}$ & Mangiferin & $\begin{array}{l}\text { Dorta et al., 2014; } \\
\text { Lasano et al., } \\
2019\end{array}$ \\
\hline 8 & 5.91 & 303.0512 & 303.0510 & 0.33 & $\begin{array}{c}20 \text { eV: } 285,257,217 \\
200,199,175,151,125 \\
107\end{array}$ & $\mathrm{C}_{15} \mathrm{H}_{12} \mathrm{O}_{7}$ & Taxifolin & $\begin{array}{l}\text { Sun et al., 2007; } \\
\text { Ye et al., 2012; } \\
\text { Metlin }\end{array}$ \\
\hline 9 & 5.93 & 435.0937 & - & - & - & - & - & - \\
\hline 10 & 6.30 & 609.1463 & 609.1461 & 0.32 & $\begin{array}{c}10 \mathrm{eV}: 301,300,271 \\
255,243,179,151\end{array}$ & $\mathrm{C}_{27} \mathrm{H}_{30} \mathrm{O}_{16}$ & $\begin{array}{l}\text { Quercetin-hexoside- } \\
\text { hexoside I }\end{array}$ & $\begin{array}{l}\text { Sun et al., 2007; } \\
\text { Said et al., } 2017\end{array}$ \\
\hline
\end{tabular}


DOI: https://doi.org/10.18554/rbcti.v5i2.4359

\begin{tabular}{|c|c|c|c|c|c|c|c|c|}
\hline Num. & $\mathbf{R t}$ & {$[\mathrm{M}-\mathrm{H}]^{-}$} & Exact mass & $\begin{array}{l}\text { Error } \\
\text { (ppm) }\end{array}$ & Fragments $\mathrm{MS}^{2}(-)$ & $\begin{array}{l}\text { Molecular } \\
\text { formula }\end{array}$ & Tentative identity & Reference \\
\hline 11 & 6.78 & 463.0881 & 463.0882 & -0.21 & $\begin{array}{c}20 \mathrm{eV}: 301,300,271 \\
255,243179,151\end{array}$ & $\mathrm{C}_{21} \mathrm{H}_{20} \mathrm{O}_{12}$ & Quercetin- hexoside & $\begin{array}{l}\text { Han et al., 2008; } \\
\text { Oliveira et al., } \\
\text { 2018; Costa Silva } \\
\text { et al., } 2019\end{array}$ \\
\hline 12 & 6.94 & 609.1461 & 609.1461 & 0.00 & $\begin{array}{c}10 \mathrm{eV}: 301,300,271 \\
255,243,179,151\end{array}$ & $\mathrm{C}_{27} \mathrm{H}_{30} \mathrm{O}_{16}$ & $\begin{array}{c}\text { Quercetin-hexoside- } \\
\text { hexoside II }\end{array}$ & $\begin{array}{l}\text { Sun et al., 2007; } \\
\text { Said et al., } 2017\end{array}$ \\
\hline 13 & 12.77 & 377.2333 & - & - & $\begin{array}{c}20 \text { eV: } 303,259,231 \\
204,163,150\end{array}$ & - & $\mathrm{NI}$ & - \\
\hline 14 & 13.30 & 405.2644 & - & - & $\begin{array}{c}20 \text { eV: } 343,331,273 \\
259,203,150,119,106\end{array}$ & - & $\mathrm{NI}$ & - \\
\hline 15 & 13.30 & 389.2693 & - & - & 25 eV: 343, 327, 287 & - & $\mathrm{NI}$ & - \\
\hline 16 & 13.70 & 255.2327 & 255.2330 & -1.18 & $\begin{array}{c}10 \text { eV: } 231,213,176 \\
148,115\end{array}$ & $\mathrm{C}_{16} \mathrm{H}_{32} \mathrm{O}_{2}$ & Palmitic acid & $\begin{array}{l}\text { Gómez-Romero } \\
\text { et al., } 2010\end{array}$ \\
\hline 17 & 14.02 & 503.3735 & - & - & $\begin{array}{c}20 \text { eV: } 469,384,344 \\
167\end{array}$ & - & $\mathrm{NI}$ & 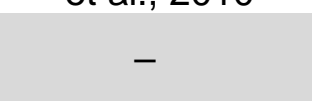 \\
\hline 18 & 14.60 & 345.2435 & 345.2435 & 0.0 & 20 eV: 301, 119, 106 & $\mathrm{C}_{22} \mathrm{H}_{34} \mathrm{O}_{3}$ & Anacardic acid (15:1) & $\begin{array}{l}\text { Erşan et al., } \\
2016\end{array}$ \\
\hline 19 & 14.82 & 371.2590 & 371.2592 & -0.54 & $\begin{array}{c}20 \mathrm{eV}: 327,133,161 \\
119,106\end{array}$ & $\mathrm{C}_{24} \mathrm{H}_{36} \mathrm{O}_{3}$ & Anacardic acid (17:2) & $\begin{array}{l}\text { Erşan et al., } \\
2016\end{array}$ \\
\hline 20 & 15.35 & 347.2592 & 347.2592 & 0.0 & 20 eV: $303,119,106$ & $\mathrm{C}_{22} \mathrm{H}_{36} \mathrm{O}_{3}$ & Anacardic acid (15:0) & $\begin{array}{l}\text { Erşan et al., } \\
2016\end{array}$ \\
\hline 21 & 15.67 & 373.2748 & 373.2748 & 0.0 & $\begin{array}{c}20 \mathrm{eV}: 329,133,119 \\
106\end{array}$ & $\mathrm{C}_{24} \mathrm{H}_{38} \mathrm{O}_{3}$ & Anacardic acid (17:1) & $\begin{array}{l}\text { Erşan et al., } \\
2016\end{array}$ \\
\hline 22 & 16.67 & 375.2905 & 375.2905 & -0.26 & $20 \mathrm{eV}: 331,119,106$ & $\mathrm{C}_{24} \mathrm{H}_{40} \mathrm{O}_{3}$ & Anacardic acid (17:0) & $\begin{array}{c}\text { Erşan et al., } \\
2016\end{array}$ \\
\hline
\end{tabular}

Rt: Retention time (minutes); NI: not identified; --: not obtained;

Metlin - Online library available at: https://metlin.scripps.edu/landing_page.php?pgcontent=mainPage 
Figure 2. Structure of the compounds identified in the EE of the twigs of $O$. obovata<smiles>O=C(O)C1(O)C[C@H](O)C(O)[C@H](O)C1</smiles>

(1)<smiles>O=C(O)c1cc(O)c(O)c(O)c1</smiles>

(2)<smiles>CC(C)OCCO</smiles>

(3)<smiles>CCOc1c(O)cc(C(=O)O)cc1O</smiles>

(6)<smiles>CO[C@H]1OC(c2c(O)cc3oc4cc(O)c(O)cc4c(=O)c3c2O)[C@H](O)[C@H](O)[C@H]1O</smiles>

(7)

Quercetin-hexoside-hexoside<smiles></smiles>

Anacardic acid (15:1)<smiles>CCCCCC/C=C/CCCCCCCc1cccc(O)c1C(=O)O</smiles>

(18)<smiles>CCCCC/C=C/C/C=C/CCCCCCCc1cccc(O)c1C(=O)O</smiles>

(19)
Taxifolin<smiles>O=C1c2c(cc(O)c(O)c2O)O[C@H](c2ccc(O)c(O)c2)[C@@H]1O</smiles>

Quercetin-hexoside<smiles>O=c1c(OC2OC(CO)C(O)C(O)C2O)c(-c2ccc(O)c(O)c2)oc2cc(O)cc(O)c12</smiles>

(11)
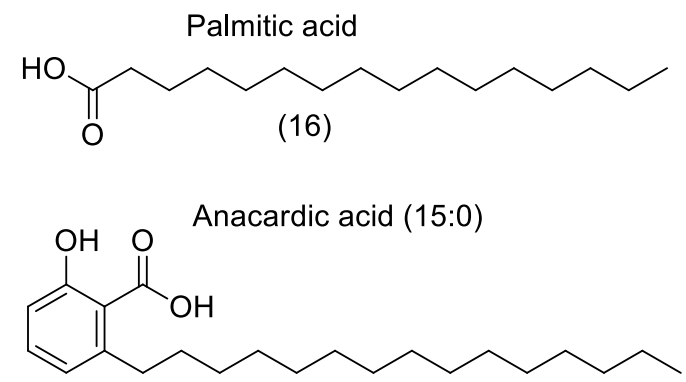

(20)<smiles>CCCCCCCC/C=C/CCCCCCCc1cccc(O)c1C(=O)O</smiles>

(21)<smiles>CCCCCCCCCCCCCCCCCc1cccc(O)c1C(=O)O</smiles>

(22) 


\section{Antimicrobial activity}

The antimicrobial activity of the ethanolic extract of the twigs of $O$. obovata was carried out using the broth microdilution method. The minimum inhibitory concentration (MIC) values for aerobic and anaerobic bacteria and yeast are shown in Table 3.

The MIC value is used as a parameter in the literature by several authors to classify the activity potential expressed by plant extracts. According to Kuete et al. (2010), MIC values below $100 \mu \mathrm{g} \mathrm{mL}^{-1}$, the activity is considered significant; between 100 to $625 \mathrm{\mu g} \mathrm{mL}^{-}$ 1 , moderate and MIC values above $625 \mu \mathrm{g} \mathrm{mL}^{-1}$, weak. Considering these parameters, $O$. obovata extract showed moderate activity for $S$. mutans, $S$. mitis and $P$. gingivalis (MIC of $400 \mu \mathrm{g} \mathrm{mL}^{-1}$ ). Regarding anti-Candida activity, the $O$. obovata extract showed a weak effect against $C$. albicans (MIC of $3000 \mu \mathrm{g} \mathrm{mL}^{-1}$ ) and was inactive against $C$. tropicalis and $C$. glabrata within the range of the tested concentrations $\left(\mathrm{MIC}>3000 \mu \mathrm{g} \mathrm{mL}{ }^{-1}\right.$ ).

Table 3. Minimum Inhibitory Concentrations (MIC, $\mu \mathrm{g} \mathrm{mL}^{-1}$ ) of the $O$. obovata extract

\begin{tabular}{|c|c|c|c|}
\hline & Microorganisms & EE & Positive Control \\
\hline \multirow{4}{*}{ 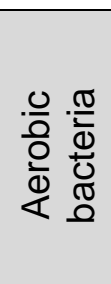 } & S. mutans & 400 & $0.92^{\mathrm{a}}$ \\
\hline & S. mitis & 400 & $3.68^{\mathrm{a}}$ \\
\hline & S. sanguinis & $>400$ & $3.68^{\mathrm{a}}$ \\
\hline & A. actinomycetemcomitans & $>400$ & $1.84^{\mathrm{a}}$ \\
\hline \multirow{3}{*}{ 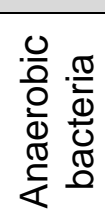 } & P. gingivalis & 400 & $3.68^{a}$ \\
\hline & F. nucleatum & $>400$ & $1.84^{\mathrm{a}}$ \\
\hline & A. naes/undii & $>400$ & $1.84^{\mathrm{a}}$ \\
\hline \multirow{3}{*}{$\begin{array}{l}\frac{\infty}{0} \\
\mathbb{J} \\
\searrow \\
\searrow\end{array}$} & C. albicans & 3000 & $0.25^{b}$ \\
\hline & C. tropicalis & $>3000$ & $0.25^{b}$ \\
\hline & C. glabrata & $>3000$ & $0.12^{b}$ \\
\hline
\end{tabular}

${ }^{\mathrm{a} C h l o r h e x i d i n e ~ d i h y d r o c h l o r i d e, ~}{ }^{\mathrm{b}} \mathrm{Amphotericin} \mathrm{B}$. Control yeasts for validation of the method by the protocol M27-A3 CLSI (2008): Candida krusei - CIM $1 \mu \mathrm{g} \mathrm{mL}^{-1}$; Candida parapsilosis - CIM $0.25 \mu \mathrm{g} \mathrm{mL}^{-1}$.

Several species of plants from Africa have already been evaluated in the literature regarding their antimicrobial potential. This is due to the wide use of medicinal plants by the population for the treatment of fevers, infectious diseases, wound healing, among others. (VAN VUUREN, 2008, NCUBE; FINNIE; VAN STADEN, 2012, VAN VUUREN; HOLL, 2017). Akhalwaya et al. (2018) evaluated the antimicrobial activity of 31 species used in folk medicine to treat oral infections. In this study, the authors considered the antimicrobial activity notorious when the leaves of Clematis brachiata exhibited MIC values below 1000 $\mu \mathrm{g} \mathrm{mL}^{-1}$ for Candida species, and when the stems of Englerophytum magalismonatanum inhibited the growth of $S$. mutans and $S$. sanguinis with concentrations of $830 \mu \mathrm{g} \mathrm{mL}^{-1}$ and $670 \mu \mathrm{g} \mathrm{mL}^{-1}$, respectively. The twigs of $O$. obovata inhibited the growth of $S$. mutans, an important etiologic agent of dental caries, with MIC value below what was considered 
notorious by these authors $\left(400 \mu \mathrm{g} \mathrm{mL}^{-1}\right)$. Thus, the antibacterial activity observed for EE of 0 . obovata twigs is relevant, particularly against cariogenic bacteria.

Regarding the Ozoroa species, 0 . mucronata and $O$. paniculosa were evaluated against various bacteria and fungi, and presented MIC values between 19-2500 and 19$1250 \mu \mathrm{g} \mathrm{mL}^{-1}$, respectively (AHMED et al., 2014). The leaves, bark and roots of 0 . reticulata showed inhibition against Gram-positive and Gram-negative bacteria with MIC values between 3.9-1000 $\mathrm{mg} \mathrm{mL}^{-1}$ (MAREGESI et al., 2008). O. engleri showed a MIC value of 750 $\mu \mathrm{g} \mathrm{mL} \mathrm{m}^{-1}$ against $C$. albicans (NAIDOO et al., 2013). These results show that the Ozoroa genus has great potential as antimicrobial agents.

The phenolic compounds identified in the EE of the twigs of $O$. obovata are well known in the literature for presenting antimicrobial activity (ZACCHINO et al., 2017, TOCCI et al., 2018, BOUARAB-CHIBANE et al., 2019, LIMA et al., 2019). Anacardic acids have also been described as having antibacterial activity against Staphylococcus aureus (MAMIDYALA et al., 2013, ANJUM et al., 2019), Streptococcus mutans (GREEN et al., 2008) and other microorganisms (KUBO et al., 1993). Although the EE of O. obovata showed moderate activity against the tested microorganisms, the presence of bioactive compounds in the twigs of this species was evidenced. Future studies of fractionation of the ethanolic extract are desired, since the concentration of bioactive compounds in fraction can increase the antimicrobial potential and better express the biological properties of the species.

In addition, investigating the presence of active metabolites in parts of plants that are not related to destructive collection, is relevant to the preservation of biodiversity and maintenance of the livelihood of people living in areas dependent on local flora.

\section{CONCLUSION}

The phytochemical screening of EE of O. obovata twigs showed the presence of phenolic acids, flavonoids, and long chain phenolic derivatives (anacardic acids) that were confirmed by HPLC-MS-ESI. These classes have already been reported in the genus and have recognized antimicrobial properties. The evaluation of antimicrobial activity showed that EE has moderate activity for oral bacteria $S$. mutans, $S$. mitis and $P$. gingivalis. The biological activity results and MS analysis are relevant because indicated the presence of active compounds justifying for advanced of antimicrobial studies with this plant. The chemical composition of $O$. obovata twigs and their antimicrobial evaluation against oral bacteria and Candida spp. are being reported here for the first time.

\section{ACKNOWLWEDGMENTS}

The authors thank the Foundation for Research Support of the Minas Gerais State (FAPEMIG-APQ-01612-18), Coordination for the Improvement of Higher Education Personnel (CAPES), Finance Code 001 and the researcher Eugénio Augusto Chilengue of the Institute of Traditional and Alternative Medicine (Ministry of Health - MISAU) for identification of the plant. 


\section{REFERENCES}

ABU-REIDAH, I. M.; ALI-SHTAYEH, M. S.; JAMOUS, R. M.; ARRÁEZ-ROMÁN, D.; SEGURACARRETERO, A. HPLC-DAD-ESI-MS/MS screening of bioactive components from Rhus coriaria L. (Sumac) fruits. Food Chemistry, v. 166, p. 179-191, 2015.

AHMED, A. S.; MCGAW, L. J.; MOODLEY, N.; NAIDOO, V.; ELOFF, J. N. Cytotoxic, antimicrobial, antioxidant, antilipoxygenase activities and phenolic composition of Ozoroa and Searsia species (Anacardiaceae) used in South African traditional medicine for treating diarrhoea. South African Journal of Botany, v. 95, p. 9-18, 2014.

AKHALWAYA, S.; VAN VUUREN, S.; PATEL, M. An in vitro investigation of indigenous South African medicinal plants used to treat oral infections. Journal of Ethnopharmacology, v. 210, p. 359-371, 2018.

ANJUM, M. M.; PATEL, K. K.; PANDEY, N.; TILAK, R.; AGRAWAL, A. K.; SINGH, S. Development of Anacardic Acid/hydroxypropyl- $\beta$-cyclodextrin inclusion complex with enhanced solubility and antimicrobial activity. Journal of Molecular Liquids, v. 296, p. 112085, 2019.

BANDEIRA, S. O.; GASPAR, F.; PAGULA, F. P. African Ethnobotany and Healthcare: Emphasis on Mozambique. Pharmaceutical Biology, v. 39, n. sup1, p. 70-73, 2001.

BARBOSA, F.; HLASHWAYO, D.; SEVASTYANOV, V.; CHICHAVA, V.; MATAVEIA, A.; BOANE, E. et al. Medicinal plants sold for treatment of bacterial and parasitic diseases in humans in Maputo city markets, Mozambique. BMC Complementary Medicine and Therapies, v. 20, n. 1, p. 19, 2020.

BEN SAID, R.; ARAFA I, H.; USAM A, M.; ABDULLAH SULAIMAN, A. A.; KOWALCZYK, M. et al. Tentative Characterization of Polyphenolic Compounds in the Male Flowers of Phoenix dactylifera by Liquid Chromatography Coupled with Mass Spectrometry and DFT. International Journal of Molecular Sciences, v. 18, n. 3, p. 1-18, 2017a.

BEN SAID, R.; HAMED, A. I.; MAHALEL, U. A.; AL-AYED, A. S.; KOWALCZYK, M.; MOLDOCH, J. et al. Tentative Characterization of Polyphenolic Compounds in the Male Flowers of Phoenix dactylifera by Liquid Chromatography Coupled with Mass Spectrometry and DFT. International journal of molecular sciences, v. 18, n. 3, p. 512, 2017b.

BOUARAB-CHIBANE, L.; FORQUET, V.; LANTÉRI, P.; CLÉMENT, Y.; LÉONARD-AKKARI, L.; OULAHAL, N. et al. Antibacterial Properties of Polyphenols: Characterization and QSAR Models. Frontiers in Microbiology, v. 10, n. 829, p., 2019.

BRUSCHI, P.; MANCINI, M.; MATTIOLI, E.; MORGANTI, M.; SIGNORINI, M. A. Traditional uses of plants in a rural community of Mozambique and possible links with Miombo degradation and harvesting sustainability. Journal of ethnobiology and ethnomedicine, v. 10, p. 59-59, 2014.

CALIXTO, J. B. The role of natural products in modern drug discovery. Anais da Academia Brasileira de Ciências, v. 91, p. 3-7, 2019.

CHAVES, M. H. Análise de extratos de plantas por CCD: uma metodologia aplicada à disciplina "química orgânica". Quimica Nova, v. 20, p. 560-562, 1997.

CHIMENOS-KÜSTNER, E.; GIOVANNONI, M. L.; SCHEMEL-SUÁREZ, M. Disbiosis como factor determinante de enfermedad oral y sistémica: importancia del microbioma. Medicina Clínica, v. 149, n. 7, p. 305-309, 2017.

CHRISTELLE, T. D.; HUSSAIN, H.; DONGO, E.; HERMINE, J.-M. B.; AHMED, I.; KROHN, K. Ozocardic A: a new alkylanacardic acid from Ozoroa pulcherrima. Journal of Asian Natural Products Research, v. 13, n. 1, p. 84-87, 2011. 
CLSI. Methods for dilution antimicrobial susceptibility tests for bacteria that grow aerobically, in CLSI Document M7-A9. 9 ed. Clinical and Laboratory Standards Institute, Wayne, PA, 2012a.

CLSI. Methods for antimicrobial susceptibility testing of anaerobic bacteria, in CLSI document M11A8. 8 ed. Clinical and Laboratory Standards Institute, Wayne, PA, 2012b.

CLSI. Reference method for broth dilution antifungal susceptibility testing of yeasts, in CLSI Document M27-A3. 34 ed. Clinical and Laboratory Standards Institute, Wayne, PA, 2008.

COSTA SILVA, T. D.; JUSTINO, A. B.; PRADO, D. G.; KOCH, G. A.; MARTINS, M. M.; SANTOS, P. D. S. et al. Chemical composition, antioxidant activity and inhibitory capacity of $\alpha$-amylase, $\alpha$ glucosidase, lipase and non-enzymatic glycation, in vitro, of the leaves of Cassia bakeriana Craib. Industrial Crops and Products, v. 140, p. 111641, 2019.

DORTA, E.; GONZÁLEZ, M.; LOBO, M. G.; SÁNCHEZ-MORENO, C.; DE ANCOS, B. Screening of phenolic compounds in by-product extracts from mangoes (Mangifera indica L.) by HPLC-ESIQTOF-MS and multivariate analysis for use as a food ingredient. Food Research International, v. 57, p. 51-60, 2014.

ERŞAN, S.; GÜÇLÜ ÜSTÜNDAĞ, Ö.; CARLE, R.; SCHWEIGGERT, R. M. Identification of Phenolic Compounds in Red and Green Pistachio (Pistacia vera L.) Hulls (Exo- and Mesocarp) by HPLCDAD-ESI-(HR)-MSn. Journal of Agricultural and Food Chemistry, v. 64, n. 26, p. 5334-5344, 2016.

GÓMEZ-ROMERO, M.; SEGURA-CARRETERO, A.; FERNÁNDEZ-GUTIÉRREZ, A. Metabolite profiling and quantification of phenolic compounds in methanol extracts of tomato fruit.

Phytochemistry, v. 71, n. 16, p. 1848-1864, 2010.

GRACE, O. M.; PRENDERGAST, H. D. V.; JÄGER, A. K.; VAN STADEN, J.; VAN WYK, A. E. Bark medicines used in traditional healthcare in KwaZulu-Natal, South Africa: An inventory. South

African Journal of Botany, v. 69, n. 3, p. 301-363, 2003.

GREEN, I. R.; TOCOLI, F. E.; LEE, S. H.; NIHEI, K. I.; KUBO, I. Design and evaluation of anacardic acid derivatives as anticavity agents. European Journal of Medicinal Chemistry, v. 43, n. 6, p. 1315-1320, 2008.

HAN, J.; YE, M.; QIAO, X.; XU, M.; WANG, B. R.; GUO, D. A. Characterization of phenolic compounds in the Chinese herbal drug Artemisia annua by liquid chromatography coupled to electrospray ionization mass spectrometry. Journal of Pharmaceutical and Biomedical Analysis, v. 47, n. 3, p. 516-525, 2008.

HOKKEN, M. W. J.; ZWAAN, B. J.; MELCHERS, W. J. G.; VERWEIJ, P. E. Facilitators of adaptation and antifungal resistance mechanisms in clinically relevant fungi. Fungal Genetics and Biology, v. 132, p. 103254, 2019.

JATSA, H. B.; FEUSSOM, N. G.; FEMOE, U. M.; KENFACK, M. C.; NKONDO, E. T.; KADJI FASSI, J. B. et al. Evaluation of the schistosomicidal, antioxidant and anti-inflammatory activities of the ethyl acetate fraction from Ozoroa pulcherrima Schweinf. Roots on Schistosoma mansoni-induced liver pathology in mice and its phytochemical characterization. Journal of Ethnopharmacology, v. 238, p. 111883, 2019.

KUBO, I.; MUROI, H.; HIMEJIMA, M.; YAMAGIWA, Y.; MERA, H.; TOKUSHIMA, K. et al. Structureantibacterial activity relationships of anacardic acids. Journal of Agricultural and Food Chemistry, v. 41, n. 6, p. 1016-1019, 1993.

KUETE, V. Potential of Cameroonian Plants and Derived Products against Microbial Infections: A Review. Planta Medica, v. 76, n. 14, p. 1479-1491, 2010. 
LASANO, N. F.; HAMID, A. H.; KARIM, R.; DEK, M. S. P.; SHUKRI, R.; SHAZINI RAMLI, N.

Nutritional Composition, Anti-Diabetic Properties and Identification of Active Compounds Using UHPLC-ESI-Orbitrap-MS/MS in Mangifera odorata L. Peel and Seed Kernel. Molecules, v. 24, n. 2, p. 320, 2019.

LIMA, M. C.; PAIVA DE SOUSA, C.; FERNANDEZ-PRADA, C.; HAREL, J.; DUBREUIL, J. D.; DE SOUZA, E. L. A review of the current evidence of fruit phenolic compounds as potential antimicrobials against pathogenic bacteria. Microbial Pathogenesis, v. 130, p. 259-270, 2019.

LIU, Y.; ABREU, P. J. M. Long chain alkyl and alkenyl phenols from the roots of Ozoroa insignis. Journal of the Brazilian Chemical Society, v. 17, p. 527-532, 2006.

MAMIDYALA, S. K.; RAMU, S.; HUANG, J. X.; ROBERTSON, A. A. B.; COOPER, M. A. Efficient synthesis of anacardic acid analogues and their antibacterial activities. Bioorganic \& Medicinal Chemistry Letters, v. 23, n. 6, p. 1667-1670, 2013.

MAREGESI, S. M.; PIETERS, L.; NGASSAPA, O. D.; APERS, S.; VINGERHOETS, R.; COS, P. et al. Screening of some Tanzanian medicinal plants from Bunda district for antibacterial, antifungal and antiviral activities. Journal of Ethnopharmacology, v. 119, n. 1, p. 58-66, 2008.

MLIGO, C. Post fire regeneration of indigenous plant species in the Pugu Forest Reserve, Tanzania. Global Ecology and Conservation, v. 18, p. e00611, 2019.

NAIDOO, D.; VAN VUUREN, S. F.; VAN ZYL, R. L.; WET, H. Plants traditionally used individually and in combination to treat sexually transmitted infections in northern Maputaland, South Africa: Antimicrobial activity and cytotoxicity. Journal of Ethnopharmacology, v. 149, n. 3, p. 656-667, 2013.

NCUBE, B.; FINNIE, J. F.; VAN STADEN, J. In vitro antimicrobial synergism within plant extract combinations from three South African medicinal bulbs. Journal of Ethnopharmacology, v. 139, n. 1, p. 81-89, 2012.

NEWMAN, D. J.; CRAGG, G. M. Natural Products as Sources of New Drugs from 1981 to 2014. Journal of Natural Products, v. 79, n. 3, p. 629-61, 2016.

NG'ANG'A, M. M.; HUSSAIN, H.; CHHABRA, S.; LANGAT-THORUWA, C.; KROHN, K. Chemical constituents from the root bark of Ozoroa insignis. Biochemical Systematics and Ecology, v., $\mathrm{n}$. 37, p. 116-119, 2009.

NYABERI, M. O.; ONYANGO, C. A.; MATHOOKO, F. M.; MAINA, J. M.; MAKOBE, M.; MWAURA, F. Bioactive fractions in the stem charcoal of Ozoroa insignis used by the pastoral communities in West Pokot to preserve milk. Journal of Applied Biosciences, v., n. 26, p. 1653 - 1658, 2010.

OLIVEIRA, D. M.; SILVA, T. F. R.; MARTINS, M. M.; MORAIS, S. A. L. D.; CHANG, R.; AQUINO, F. et al. Antifungal and cytotoxicity activities of Banisteriopsis argyrophylla leaves. Journal of Pharmacy and Pharmacy, v. 70, n. 11, p. 1541-1552, 2018.

PAN, S. Y.; LITSCHER, G.; GAO, S. H.; ZHOU, S. F.; YU, Z. L.; CHEN, H. Q. et. al. Historical perspective of traditional indigenous medical practices: the current renaissance and conservation of herbal resources. Evidence-based complementary and alternative medicine : eCAM, v. 2014, p. 525340-525340, 2014.

PERLIN, D. S.; RAUTEMAA-RICHARDSON, R.; ALASTRUEY-IZQUIERDO, A. The global problem of antifungal resistance: prevalence, mechanisms, and management. The Lancet Infectious Diseases, v. 17, n. 12, p. e383-e392, 2017.

PRESTINACI, F.; PEZZOTTI, P.; PANTOSTI, A. Antimicrobial resistance: a global multifaceted phenomenon. Pathogens and global health, v. 109, n. 7, p. 309-318, 2015. 
ROCHA, E. O.; CUNHA, L. C. S.; SILVA, M. V. S. G.; FREITAS, T. R.; NASCIMENTO, E. A.; SILVA, L. O. et al. Composição química e atividade antimicrobiana do óleo essencial das flores de Banisteriopsis campestris (A. Juss.) Little. Revista Virtual de Quimica, v. 10, n. 5, p. 1562-1577, 2018.

SAID, R. B.; HAMED, A. I .; MAHALEL, U. A.; AL-AYED, A. S.; KOWALCZYK, M.; MOLDOCH, J. et al. Tentative characterization of polyphenolic compounds in the male flowers of Phoenix dactylifera by liquid chromatography coupled with mass spectrometry and DFT. International Journal of Molecular Science, v. 18, n. 3, p. 1-18, 2017.

SEN, T.; SAMANTA, S. K. Medicinal Plants, Human Health and Biodiversity: A Broad Review. In: MUKHERJEE, J. Biotechnological Applications of Biodiversity, Berlin, Heidelberg: Springer Berlin Heidelberg, 2014. p. 59-110.

SHARIFIFAR, F.; ANSARI DOGAHEH, M.; ESLAMINEJAD, T.; OHADI, M.; DOUZANDEH MOBARREZ, B. et al. Antimicrobial Potency of Plant Species: A Review. European Journal of Medicinal Plants, v. 11, p. 1-17, 2016.

SIMOES, C. M. O.; SCHENKEL, E. P.; MELLO, J. C. P.; MENTZ, L. A.; PETROVICK, P. R. Farmacognosia do produto natural ao medicamento. Porto Alegre: Artmed, 2017. 486 p.

SINGH, R. Medicinal plants: A review. Journal of Plant Sciences, v. 3, n. 1-1, p. 50-55, 2015.

SUN, J.; LIANG, F.; BIN, Y.; LI, P.; DUAN, C. Screening Non-colored Phenolics in Red Wines using Liquid Chromatography/Ultraviolet and Mass Spectrometry/Mass Spectrometry Libraries.

Molecules, v. 12, n. 3, p. 679-693, 2007.

TIMMERMANN, L.; SMITH-HALL, C. Commercial Medicinal Plant Collection Is Transforming Highaltitude Livelihoods in the Himalayas. Mountain Research and Development, v. 39, n. 3, p. 1321, 2020.

TOCCI, N.; WEIL, T.; PERENZONI, D.; NARDUZZI, L.; MADRIÑÁN, S.; CROCKETT, S. et al. Phenolic profile, chemical relationship and antifungal activity of Andean Hypericum species. Industrial Crops and Products, v. 112, p. 32-37, 2018.

VAN VUUREN, S.; HOLL, D. Antimicrobial natural product research: A review from a South African perspective for the years 2009-2016. Journal of Ethnopharmacology, v. 208, p. 236-252, 2017.

VAN VUUREN, S. F. Antimicrobial activity of South African medicinal plants. Journal of Ethnopharmacology, v. 119, n. 3, p. 462-472, 2008.

WAGNER, H.; BLADT, S. Plant drug analysis: a thin layer chromatography atlas. 2. ed. Berlin: Springer, 1996. 384 p.

WHITE, T. C.; FINDLEY, K.; DAWSON, T. L., JR.; SCHEYNIUS, A.; BOEKHOUT, T.; CUOMO, C. A. et al. Fungi on the skin: dermatophytes and Malassezia. Cold Spring Harbor Perspectives in Medicine, v. 4, n. 8, p. a019802, 2014.

WHO. World Health Organization. 2020. Available in: <https://www.who.int/news-room/factsheets/detail/antimicrobial-resistance>. Access in: Feb. 2020.

WÜRGER, G.; MCGAW, L. J.; ELOFF, J. N. Tannin content of leaf extracts of 53 trees used traditionally to treat diarrhoea is an important criterion in selecting species for further work. South African Journal of Botany, v. 90, p. 114-117, 2014.

WYREPKOWSKI, C. C.; COSTA, D. L. M. G. D.; SINHORIN, A. P.; VILEGAS, W.; DE GRANDIS, R. A.; RESENDE, F. A. et al. Characterization and quantification of the compounds of the ethanolic extract from Caesalpinia ferrea stem bark and evaluation of their mutagenic activity. Molecules, v. 19, n. 10, p. 16039-16057, 2014. 
YE, M.; YANG, W. Z.; LIU, K. D.; QIAO, X.; LI, B. J.; CHENG, J. et al. Characterization of flavonoids in Millettia nitida var. hirsutissima by HPLC/DAD/ESI-MS (n). Journal of pharmaceutical analysis, v. 2, n. 1, p. 35-42, 2012.

YORK, T.; WET, H.; VAN VUUREN, S. F. Plants used for treating respiratory infections in rural Maputaland, KwaZulu-Natal, South Africa. Journal of Ethnopharmacology, v. 135, n. 3, p. 696710, 2011.

YORK, T.; VAN VUUREN, S. F.; DE WET, H. An antimicrobial evaluation of plants used for the treatment of respiratory infections in rural Maputaland, KwaZulu-Natal, South Africa. Journal of Ethnopharmacology, v. 144, n. 1, p. 118-127, 2012.

ZACCHINO, S. A.; BUTASSI, E.; LIBERTO, M. D.; RAIMONDI, M.; POSTIGO, A.; SORTINO, M. Plant phenolics and terpenoids as adjuvants of antibacterial and antifungal drugs. Phytomedicine, v. 37, p. 27-48, 2017.

ZARCO, M.; VESS, T.; GINSBURG, G. The oral microbiome in health and disease and the potential impact on personalized dental medicine. Oral Diseases, v. 18, p. 109-120, 2011. 